\title{
Training of argon arc welding process for tube aluminum busbar melting pole in UHV power station
}

\author{
Liyang, Hanyang, Tangyanling \\ State Grid of China Technology, Ji'nan, Shandong 250000, China
}

\begin{abstract}
The development of power grid is showing that voltage level is from low to high, networking scale is from small to large, level of automation is from weak to strong.. [1] as the hub of power grid connection between substations, the capacity and automation level of substations is also improving. The large diameter and thick walled tubular busbars of substations have been widely applied. Because of the wide application of tubular aluminum busbar, its welding quality has affected the overall quality of the power plant. Therefore, it is an effective way to improve welding level of power station busbar by scientifically making technological measures and welding codes and carrying out adaptive training for welding operators. In view of the feasibility of the argon arc welding (MIG) welding process and the feasibility of training for the tubular aluminum busbar of UHV power station, the characteristics of the welding technology of tubular aluminum busbar and the technological measures taken by the welding technicians are discussed.
\end{abstract}

\section{Introduction}

Since 12th Five-Year, along with the acceleration of the construction of the national UHV power grid, the scale and schedule of the substation construction have also been improved. The TIG has been promoted and applied in the welding of substation buses with its high efficiency and high quality. The melting pole argon arc welding is the welding method that produces arc between the continuous wire and the workpiece, and the molten weld metal is connected. The arc and molten pool are protected by gas or mixed gas sprayed by the welding gun nozzle. If argon or helium is used as protective medium, it is called MIG welding. In recent years, we have carried out related training work for the welding characteristics of the overhead busbar. After several years of research and practice, we have discussed further the training technology of the horizontal fixed welding for the $\mathrm{V}$ type groove pipe butt joint on the back of the overhead pipe type and the undetachable backing plate on the back side.

\section{Specific process}

\subsection{Analysis of welding characteristics}

Aluminum and its alloys are oxidable. They are easy to produce oxides $\left(\mathrm{Al}_{2} \mathrm{O}_{3}\right)$ in air and welding process. $\mathrm{Al}_{2} \mathrm{O}_{3}$ has the characteristics of high melting point, high stability and strong adhesion. It is easy to form pores, non fusion, incomplete penetration and slag inclusion in weld. Secondly, aluminum and its alloys are relatively high in terms of thermal conductivity, electrical conductivity, linear expansion coefficient and specific heat capacity relative to steel, while density and melting point are much lower than steel. Therefore, weldability is much worse than steel. Therefore, the welding seam is cleaned before welding process, and the quality of weld is ensured by selecting high purity welding gas and materials, which is especially important for avoiding the occurrence of blowholes and other defects.

In the welding process of aluminum and its alloy, it is very easy to produce cracks. The stress of the welding joint is large and the heat output of welding is the most important factor to produce the crack. The selection of suitable welding methods, process parameters and reasonable assembly order are the main measures to prevent weld cracks. ${ }^{[2]}$

\subsection{Selection of welding materials and equipment}

The selection of welding wire: when selecting welding wire, it is necessary to meet the requirements of chemical composition, mechanical properties and electrical conductivity of welded joints, as well as good weldability. In order to meet the needs of performance and weldability, priority should be given to chemical components and corresponding or similar welding wires of base metal. We use the training specimen material selection with the same $6063(\Phi 250 \times 10$ ) heat treatment Aluminum Alloy tube type bus, because it belongs to the AL-Mg-Si Department of Aluminum Alloy, so we select of Alcotec ER4043, $\Phi$ 1.6 wire.

Selection of protective gases: MIG welding aluminum alloy tubular bus is very demanding for argon purity. In order to prevent welding defects due to the 
lack of purity of gas, argon is selected as the protective gas with purity of $99.99 \%$ (volume fraction). ${ }^{[3]}$

Pad: because that the aluminum and Aluminum Alloy have low strength and low liquid liquidity in high temperature, in the process of welding the weld metal prone to collapse, in order to ensure the root layer penetration without causing collapse and welding weld defects, it should be used to support plate weld pool and base metal welding. Therefore, when welding aluminum alloy pipe type busbar, the aluminum material with the same material and specifications as the base material can be used as the cushion plate.

Welding equipment: because the typical training project selected for substation construction is "V type groove pipe butt horizontal fixed" welding. In order to effectively control the pool shape and get good weld shape, we choose the high frequency pulsed MIG welding equipment. Because of the high frequency pulse MIG welding, even if the average current is less than the critical value of jet transition, jet transition can also be achieved. Therefore, its smaller welding heat output is more conducive to the welding of $\mathrm{V}$ groove pipe butt weld.

\subsection{Key points of operation}

Pre welding preparation: the training samples are machined. Because of the long production cycle and the presence of dirt and oxides on the surface, mechanical cleaning should be used before cleaning.

A copper brush with a diameter of $0.15 \mathrm{~mm}-0.2 \mathrm{~mm}$ or a stainless steel brush is used to clean up the specimen. When is cleaning, it should be carried out repeatedly in the range of the slope and its two sides of the $20 \mathrm{~mm}$, until the metallic luster is revealed.

Under normal conditions, it is not suitable to use grinding wheel or ordinary sand paper for grinding, so as to avoid the residue on the metal surface, when it is welding into the weld pool to produce defects. In addition, $t$ The edge of the specimen can be cleaned up by a file or scraper. ${ }^{[4]}$

Positioning welding: the location of solder joints is a part of the weld. In order to ensure the quality of the weld, the same welding process and specification should be used in the same way as the formal welding. The number of positioning of the joints, along the circumferential weld every $120^{\circ}$ positioning point, should not be less than 3 points, its length should be less than $20 \mathrm{~mm}$. Repair at both ends of the solder joint before the formal welding is made, so that the welding joint can be fully melted. After the welding operation is completed, the appearance of the weld is checked, and the formal welding can be carried out after the defect is confirmed.

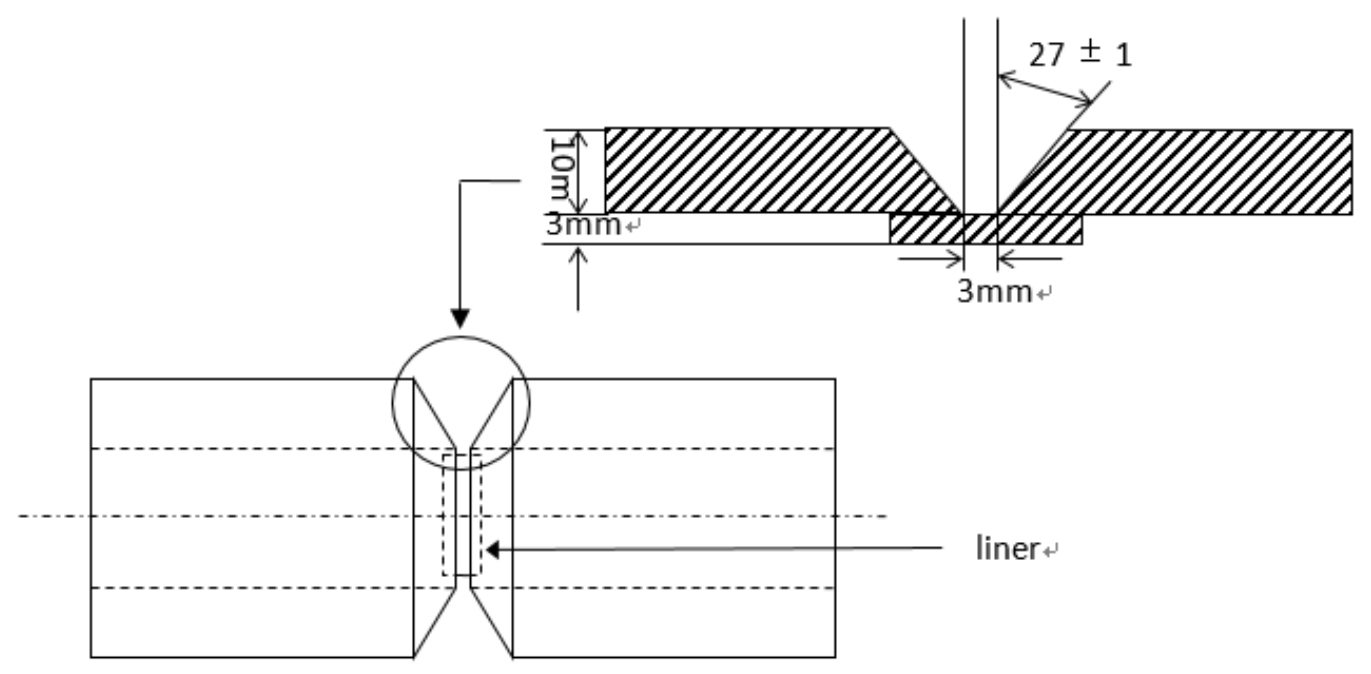

Figure 1 liner assembly and slope indication

Welding process parameters: the right choice of equipment, current, voltage and protective gas flow will play a key role in reducing the welding porosity and improving the weld quality of aluminum alloy busbar. The groove form and welding specifications are shown in (Figure 1, table 1).

Table 1 Welding procedure specification

\begin{tabular}{|c|c|c|c|c|c|c|c|}
\hline $\begin{array}{c}\text { Thickness } \\
\text { of } \\
\text { weldment } \\
(\mathrm{mm})\end{array}$ & $\begin{array}{c}\text { Welding } \\
\text { equipment }\end{array}$ & $\begin{array}{c}\text { welding } \\
\text { wire } \\
(\mathrm{mm})\end{array}$ & $\begin{array}{c}\text { welding } \\
\text { current } \\
(\mathrm{A})\end{array}$ & $\begin{array}{c}\text { Welding } \\
\text { voltage } \\
(\mathrm{V})\end{array}$ & $\begin{array}{c}\text { Wire feeding } \\
\text { speed } \\
(\mathrm{m} / \mathrm{min})\end{array}$ & $\begin{array}{c}\text { Argon flow } \\
\text { rates (L/min) }\end{array}$ & $\begin{array}{c}\text { Number of } \\
\text { welding } \\
\text { layers }\end{array}$ \\
\hline 10 & $\begin{array}{c}\text { Monopulse } \\
\text { MIG }\end{array}$ & 1.6 & $180-220$ & $24-26$ & $4.5-6.2$ & $20-25$ & 2 \\
\hline
\end{tabular}


The aluminum alloy pipe type busbar is formally welded, and the arrangement of the weld is two layers and two welds. Correct operation method is also very important for forming and quality of weld, including welding torch angle, arc length, distance between nozzle and workpiece, etc.

Bottom welds welding: the arc starts from weld clock 6 point, after ensuring the fusion of both sides of the slope and the cushion plate, uninterrupted clockwise moves the welding on to clock 12 points, and then you shloud repair the arc starting and stopping at the junction to the slopes. the arc starts around at the 5 point of the clock, $t$ The joint is welded quickly to the 6 point of the clock by the stable burning of the arc., and observe the joint fully fused counter clockwise to clock the 1 point arc welding.

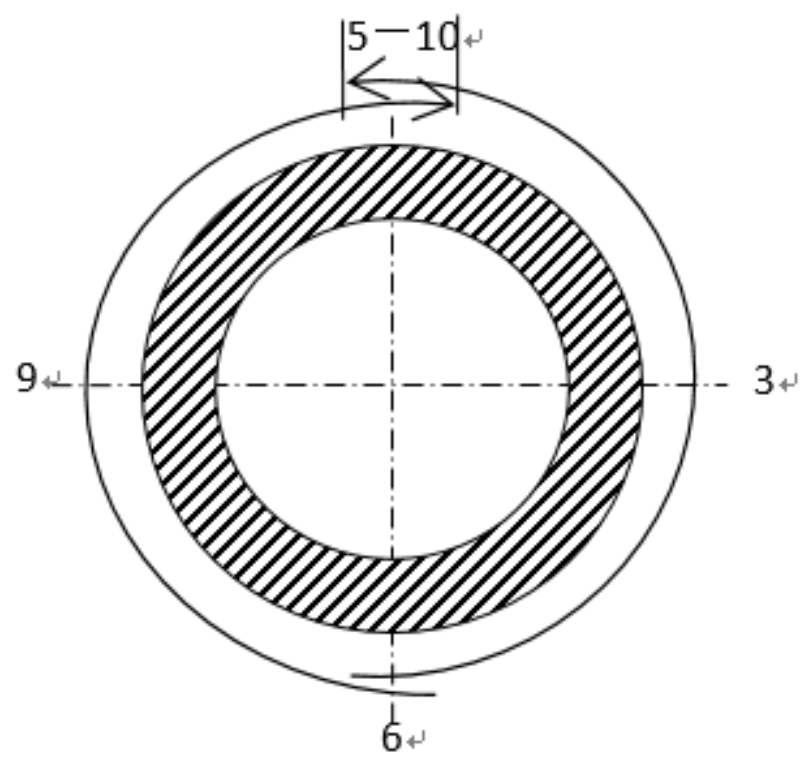

Figure 2 Direction and sequence of welding

Cover layer welding: Before the cover is welded, the oxide on the weld surface of the bottom layer should be thoroughly cleaned and the weld seam at the joint is treated smoothly. The welding direction and order of the cover layer are in accordance with the bottom layer. It is worth noting that in the arc starting and stopping the joint operation, should be zigzag swing, to fill in the hole behind the arc.
Try to keep in the process of welding arc length and arc angle of welding gun, welding torch inclination is too low or too big will cause a lot of spatter, it will penetrate the protective gas, so that the air into the weld pool wll leads to weld defect; welding process should be adopted for small amplitude zigzag welding gun swing, swing the protection will cause turbulence gas, the air is also brought into the weld pool to produce welding defects..
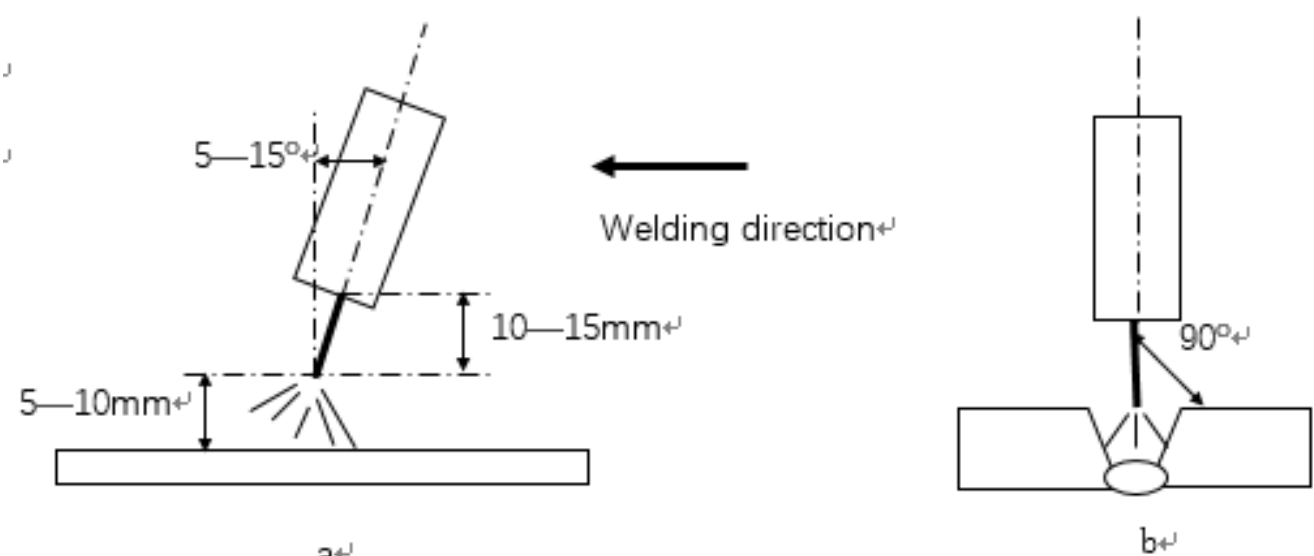

b

Figure 3 Schematic diagram of operation specification 
Post weld inspection (according to electric power industry standard "technical specification for busbar welding" DL/T754 - 2013). ${ }^{[5]}$
The weld appearance size and the weld surface quality shall be in accordance with the provisions in table 2 , table 3 respectively.

Table 2 Welding procedure specification

\begin{tabular}{|c|c|c|c|c|c|c|}
\hline \multirow{2}{*}{ type } & \multicolumn{2}{|c|}{ Weld residual height } & \multicolumn{2}{c|}{$\begin{array}{c}\text { Surface weld height } \\
\text { difference }\end{array}$} & \multicolumn{2}{c|}{ Weld width } \\
\cline { 2 - 6 } & $\begin{array}{c}\text { Plane } \\
\text { position } \\
\text { welding }\end{array}$ & $\begin{array}{c}\text { Other } \\
\text { positions }\end{array}$ & $\begin{array}{c}\text { Plane } \\
\text { position } \\
\text { welding }\end{array}$ & Other positions & $\begin{array}{c}\text { Widening of } \\
\text { both sides }\end{array}$ & $\begin{array}{c}\text { Widening of } \\
\text { each side }\end{array}$ \\
\hline Docking & $\begin{array}{c}2 \mathrm{~mm}-4 \\
\mathrm{~mm}\end{array}$ & $\begin{array}{c}2 \mathrm{~mm}-4 \\
\mathrm{~mm}\end{array}$ & $\leq 2 \mathrm{~mm}$ & $\leq 2 \mathrm{~mm}$ & $2 \mathrm{~mm}-4 \mathrm{~mm}$ & $1 \mathrm{~mm}-2 \mathrm{~mm}$ \\
\hline
\end{tabular}

Table 3 limits of weld surface defects

\begin{tabular}{|c|c|}
\hline Defect name & Limits \\
\hline Crack, non fusion, dense gas hole, burning through & Not allow \\
\hline Non weld penetration & Not allow \\
\hline Undercut & $\begin{array}{l}\text { The depth is not more than } 10 \% \text { of the thickness of } \\
\text { the weldment and is not more than } 1 \mathrm{~mm} \text {, and the } \\
\text { length is not more than } 20 \% \text { of the length of the } \\
\text { weld. }\end{array}$ \\
\hline Protruding and pits in the root & $\begin{array}{l}\text { The backside of the pad is not allowed to be } \\
\text { penetrated and welded through the pits. }\end{array}$ \\
\hline
\end{tabular}

The bending deformation of the weldment should not be greater than the single specimen length $0.2 \%$, the wrong port value (Center) should be less than $0.5 \mathrm{~mm}(\leqslant$ $0.15 \delta$ and not more than $3.0 \mathrm{~mm}$ ).

The radiographic inspection of welded joints shall be carried out according to the relevant requirements of appendix D in DL/T 754 - 2013 of busbar welding technology specification, and the quality of radiation is higher than second level and above is qualified.

\section{Conclusion}

The MIG welding training of aluminum alloy tubular bus is a technical means to maintain the construction link of the ATC bus bar and an effective way to ensure the operation of the whole power grid construction system. MIG welding provides support for the construction of substation for its high efficiency and high quality. Through training for typical projects in substations, trainees can adapt to the actual welding environment as soon as possible, and enter into practice production with standardized and standard welding operation essentials. This will greatly improve the quality of welding and shorten the construction period. Only by scientific formulation and strict implementation of welding technical measures can the engineering quality of aluminum alloy pipe type busbar welded joint be guaranteed.

\section{References}

1. Liu Zhenya. Global energy Internet [M]. Beijing: China Electric Power Press, 2015. 200-200.

2. Zou Cheng. Welding manual (welding of materials) [M]. Beijing: Machinery Industry Press, 2008.596597.

3. Zhang Yanmin. International welder training [M]. Harbin: Heilongjiang people's publishing house, 2002. 57-57.

4. Li Yajiang. Non-ferrous metal welding and application [M]. Beijing: Chemical Industry Press, 2006. 37-38.

5. DLT 754-2013, technical specification for busbar welding $[\mathrm{S}]$. 